\title{
EDITORIAL
}

\section{“... E o XIV SNEF aconteceu"}

Como bem demonstrou o XIV Simpósio Nacional de Ensino de Física (SNEF), realizado de 02 a 06 de julho de 2001 em Natal, existem capacidades e possibilidades de abrir o país para os nossos encontros de ensino de física e de abrir os nossos encontros para o país. Devemos reconhecer que o que conta no Brasil não são apenas os estados do Sudeste e Sul. Assim, admitimos que as mudanças de data e local ocorridas para o XIV SNEF em nada afetaram a realização do evento como um todo. Provavelmente foi mais difícil e custoso para aqueles que ficaram com a responsabilidade de fazer o evento acontecer... Mas aconteceu, e é isso o que vale, quando fazemos a avaliacão final. Temos assim muito que agradecer à Coordenação local, e às autoridades da UFRN, que se empenharam para que o evento acontecesse.

Do ponto de vista da programação acredito que o tema do encontro, 'Educação Científica, Cultura e Qualidade de Vida' seja ainda um assunto difícil de desenvolver para os participantes do Simpósio, e precisamos amadurecer muito nessa linha de conhecimento. Penso que a discussão sobre o assunto ficou aquém do esperado, ou pelo menos, do que eu gostaria de ter ouvido. Isso pode ser compreendido pela necessidade de associar componentes de uma cultura mais universal aos tópicos com que estamos habituados a lidar. Há que se dar tempo ao tempo.

Inspecionando o programa, as oficinas (27) e os cursos (25) apresentaram assuntos bem diversificados, mais relacionados com ensino de física, desenvolvimento de materiais didáticos, aplicação de novas tecnologias, história e filosofia da ciência em sala de aula e a formação de professores. A física moderna começa, mesmo que tardiamente, a ser discutida, o que é muito bom. Dentre as oficinas que abordaram os temas cultura e qualidade de vida apareceram assuntos interessantes como 'Física e Música', 'Alfabetização Cientifica'. Algumas palestras curiosas discutiram uma nova proposta sobre a "Universidade Indígena", e outra sobre aspectos da "Ética Profissional e Qualidade de Vida". Como sempre, as oficinas e cursos constituem uma componente muito solicitada, sua utilidade está fora de discussão e é sempre necessário assegurar que a qualidade dos materiais utilizados esteja de acordo com aquilo que é prometido.

É interessante destacar que dentre os debates programados, o 'Cultura e Ensino de Física' contou com o maior número de participantes. Outro que especificamente deveria ter atraído os participantes interessados pelo seu oportuno tema: 'Física para Estudantes de Humanidades' foi praticamente esvaziado, e acabou acontecendo apenas uma discussão entre um grupo de participantes "mais velhos" que reconhecem ser este um assunto importante e que deve entrar em discussão, caso se deseje um ensino de "física mais humanista". O que seja isso é difícil de definir, mas há concordância que possa vir a contribuir para a alfabetização científica da população como um todo. Os PCN tiveram vários destaques, mas também, em que pese o consenso acerca da sua contribuição importantíssima para uma virada positiva dos currículos e do ensino da física escolar, as críticas foram muitas e a dificuldade de operacionalizálos, no atual contexto da escola básica brasileira, levam muitos professores a um pessimismo, que mesmo compreensível, parece às vezes exagerado.

As sessões de painéis, com acima de 220 contribuições, mostraram muita vitalidade e uma grande diversidade de assuntos, muitos trabalhos excelentes realizados com a colaboração de estudantes dos cursos de licenciatura e da pós-graduação. Houve (muitos) participantes que acham que esta atividade per se já justifica a participação no Simpósio.

Acho que algumas palestras ou conferências sobre assuntos nos quais a física brasileira desenvolve pesquisas atualmente deveriam fazer parte da programação e senti sua falta. Debates com pesquisadores teóricos e experimentais devem ter espaço garantido. Senti falta também dos debates entre pesquisadores em ensino de física e em física fundamental sobre a problemática do ensino da física na universidade e a formação dos professores, assuntos que requerem discussão conjunta à procura de soluções comuns.

A Coordenação do Simpósio, como sempre acontece, sofreu as conseqüências dos problemas de financiamento, que sempre se resolvem apenas na última hora. Conseguiu reunir colegas interessados que organizaram mostras, dentre estas uma bem escolhida apresentação das Atas dos SNEFs anteriores. O câmpus da UFRN e os prédios comportaram o contingente de visitantes, em que pese o fato da Universidade ainda estar em período letivo.

É minha modesta opinião, após ter participado de todos os SNEFs - exceto o primeiro, de dezembro de 1970, realizado em Salvador e o único dos anteriores realizado no Nordeste -, que este encontro se encontra no mesmo patamar de qualidade dos demais SNEFs, cujo principal objetivo foi sempre motivar novos grupos de professores de física e alunos dos cursos de licenciaturas, facilitar novas parcerias e colocar à disposição o rico acervo das realizações no campo do Ensino de Física no Brasil.

Este SNEF apontou também indicadores que deverão ser levados em conta no futuro, se desejamos que a Sociedade Brasileira de Física, à semelhança das 
suas 'irmãs' de outros países, como por exemplo a American Association of Physics Teachers e o Institute of Physics, da Inglaterra, integre ações significativas para a melhoria do ensino de física no país. No caso das sociedades estrangeiras, houve uma conscientização do que significa a contribuição do ensino de física, das pesquisas nessa área e da necessidade por parte dos institutos e departamentos de física de prestar atenção e utilizar recursos para melhorar um ensino que está com problemas como se sabe há bastante tempo [ver Ruth $\mathrm{H}$. Howes em RBEF 22 (4), 510 (2000)].

No nosso caso específico, as dificuldades de se administrar este tipo de evento, longe da sede da SBF, com recursos locais limitadíssimos, e sem apoio direto da Secretaria são notórias. Seria importante que os recursos gerados pelo próprio SNEF fossem compartilhados, para facilitar a organização e evitar as dificuldades desnecessárias inerentes à organização. Estes e outros aspectos críticos foram levantados na assembléia final do SNEF e deveriam constituir o ponto de partida de uma nova parceria entre o grupo de Ensino de Física da SBF e o resto dos físicos que constituem o grosso da SBF, e que, como físicos e professores, têm consciência das dificuldades enfrentadas no cotidiano junto aos seus alunos.

Para falar das evidências, as estatísticas mostram que houve, em que pese os sempre ativos pessimistas de plantão, uma freqüência que excedeu os 600 inscritos, dos quais um número muito significativo constituído de professores do ensino médio assim como um grande contingente de alunos das licenciaturas de física. Este grupo dá suporte e mostra que os SNEFs representam realmente uma atividade relevante e que contribuem positivamente para o ensino de física no país.

Susana de Sousa Barros

IF-UFRJ

Membro da Comissão de Ensino da SBF. 